\title{
The impact of Septoria tritici blotch in bread making quality among argentinean wheat cultivars
}

\author{
Ana Carolina Castro a, b, *, María Rosa Simón ${ }^{\text {a, c }}$ \\ ${ }^{a}$ Cerealicultura, Facultad de Ciencias Agrarias y Forestales, Universidad Nacional de La Plata, Av. 60 y 119 La Plata, Buenos Aires, Argentina \\ ${ }^{\mathrm{b}}$ Consejo Nacional de Investigaciones Científicas y Técnicas (CONICET) CCT La Plata, Calle $8 \mathrm{~N}^{\circ} 1467$ La Plata, Buenos Aires, Argentina \\ ${ }^{\mathrm{c}}$ Comisión de Investigaciones Científicas (CIC), Calle 526 e/ 10 y 11 La Plata, Buenos Aires, Argentina
}

\section{A R T I C L E I N F O}

\section{Article history:}

Received 6 April 2017

Received in revised form

8 August 2017

Accepted 30 August 2017

Available online 31 August 2017

\section{Keywords:}

Wheat

Septoria tritici blotch

Bread making quality

Rheological properties

\begin{abstract}
A B S T R A C T
Septoria tritici blotch (STB), caused by Zymoseptoria tritici is a relevant foliar wheat disease worldwide. Several reports show the importance of STB on grain yield, their components and grain protein while little is known about its effect on the rheological properties of the wheat flour. The scarce literature found, only mentions the effect of the complex of foliar diseases on wheat quality, without individualizing the effect of the different pathogens separately. This study analyze the influence of increasing doses of inoculum of Zymoseptoria tritici, on the bread making quality of ten Argentinean wheat cultivars and its possible variation according to their quality group. The increase of inoculum concentration augmented the area under disease progress curve, decreased green flag leaf area duration and green leaf area duration. Cultivars K. Flecha and B.75 Aniversario had the lowest green flag leaf area duration causing higher reduction in grain filling period and higher reductions in P, indicating a lower gliadin/ glutenin ratio. STB decreased $\mathrm{P} / \mathrm{L}$ and $\mathrm{E}$ while $\mathrm{L}, \mathrm{W}, \mathrm{D}, \mathrm{SV}$ and bread volume increased. Cultivars differed in rheological parameters according to their quality group. Gluten/protein relationship was significant in quality group 1 and non-significant in cultivars belonging to quality group 2 and 3 .
\end{abstract}

(c) 2017 Elsevier Ltd. All rights reserved.

\section{Introduction}

Wheat (Triticum aestivum L.) is an essential crop in human food, which is grown on 222 million hectares worldwide and is a major source of calories and proteins globally (USDA, 2016). The modern baking industry requires a high level of uniformity in wheat quality to meet the demands of the automated processing facilities they use (Finlay et al., 2007). Two important determinants of this quality are the amount of grain protein, which is strongly influenced by environmental factors, and the protein composition, which is determined by both genetics and environment (Dupont and Altenbach, 2003). Literature revealed that a stress during grain

Abbreviations: STB, Septoria tritici blotch; GY, grain yield; GPC, grain protein concentration; GS, growth stage; G1, group 1; G2, group 2; G3, group 3; AUDPC, area under disease progress curve; GLAD, green leaf area duration; GFLAD, green flag leaf area duration; BV, bread volume; BW, bread weight; SV, specific volume; NI, non-inoculated; LIC, low inoculum concentration; HIC, high inoculum concentration.

* Corresponding author. Cerealicultura, Facultad de Ciencias Agrarias y Forestales, Universidad Nacional de La Plata, Av. 60 y 119 La Plata, Buenos Aires, Argentina.

E-mail address: ingeniera.anacastro@gmail.com (A.C. Castro). filling causes changes in gliadin/glutenin ratio and this has an impact in rheological properties (Stone and Savin, 1999). Thus, obtaining the desired quality is not a simple task since it is influenced by the environment, management, genetic and particularly by the presence of foliar diseases that may affect wheat quality.

The effect of foliar diseases on grain yield (GY), test weight and grain weight was mentioned in the past, but little information was reported about the effect of foliar diseases on breadmaking quality. Septoria tritici blotch (STB), caused by the ascomycete fungus Zymoseptoria tritici is one of the most important foliar wheat diseases in the world due to significant losses in GY and quality (Fones and Gurr, 2015). Likewise, in Argentina there are several reports that show the importance of STB on GY, their components and grain protein (Simón et al., 2002; Castro and Simón, 2016) while little is known about its effect on the rheological properties of the wheat dough.

Considering the influence of crop management on quality, the effect of fungicides on grain protein concentration (GPC) depends, among other factors, on the nutritional habit of the pathogen. In this sense, Dimmock and Gooding (2002a) observed that when classic biotrophs are controlled, the GPC often increases. Therefore, 
the pathogen has a more damaging effect on the accumulation and partitioning of nitrogen to the grain, than it does on the accumulation and partitioning of the dry matter. Conversely, most reports of the effect of controlling necrotrophic pathogens found that fungicide use is associated with a reduction in GPC, thus the pathogen increases it (Rees et al., 1982). Zymoseptoria tritici is a hemibiotrophic pathogen, and its effects on GPC varied among studies. McKendry et al. (1995) found that increased disease pressure of STB resulted in a significant increase in flour protein, whereas Castro and Simón (2016) found that the increase in inoculum concentration of STB augmented grain protein and gluten concentration. In contrast, Arabi et al. (2007) showed that protein content decreased significantly in cultivars severely infected by STB. In addition, some authors found that the use of fungicide to control STB reduced or had no effect on GPC (Ishikawa et al., 2001; Ruske et al., 2001).

Literature about the effect of foliar wheat diseases on breadmaking quality is scarce. In Argentina, Fleitas et al. (2016) found that the rheological parameters were affected differentially according to the dominant foliar disease. Thus, tan spot (Pyrenophora tritici-repentis) (Died) Shoem anamorph Drechslera tritici repentis Died Shoemaker produced a decreased in tenacity $(P)(9.54 \%)$ but increased dough strength $(\mathrm{W})(14.7 \%)$ significantly compared to leaf rust (Puccinia triticina Eriks.). According to the studies carried out by Cuniberti et al. (2004), in most cultivars affected by leaf rust and tan spot, the $\mathrm{W}$ and bread volume (BV) values fall, showing a negative effect of fungicide treatment on the breadmaking quality. Specifically, considering the effects of STB, González Montaner and Di Nápoli (2005) pointed out that when fungicides are used to control STB around growth stage (GS) 50-59 (Zadoks et al., 1974), there are negative effects on quality parameters, particularly on $\mathrm{W}$ and D (farinographic stability).

The effect of STB on quality parameters, may also varied, depending on the wheat quality of each cultivar. The Argentine Winter Cereals Committee of the National Seeds Institute (INASE), classifies wheat cultivars according to their industrial end-use properties into three quality groups: quality group 1 (G1) corresponds to the highest quality cultivars, suitable for industrial breadmaking; quality group 2 (G2) corresponds to traditional breadmaking cultivars suitable for major long fermentations (higher than eight hours) and quality group 3 (G3) includes cultivars with the lowest quality and with short fermentation times (up to eight hours). This categorization is the current official classification based on test weight, grain protein, flour yield, ash content, \% wet gluten concentration, W, D and BV. Cultivars corresponding to each group present values within a similar range for the mentioned parameters.

Indeed, Dimmock and Gooding (2002a) found that it is reasonable to suppose that cultivars specially bred for bread making quality may be able to maintain grain nitrogen accumulation more effectively as senescence is delayed and yield increases, compared with cultivars for biscuits where protein concentration is much less important. Thus, Puppala et al. (1998) reported large increases in protein concentration following fungicide use on a cultivar specifically bred for bread making (high protein concentration) affected by a complex of disease where STB was observed.

There is little information worldwide about the effect of foliar diseases in quality parameters such as rheological properties that are considered of great importance in determining the baking quality of wheat flours. In addition, most of the scarce literature found, only mentions the effect of the complex of foliar diseases on the wheat quality, without individualizing the effect of each pathogen separately. That is why, the aim of this study was to analyze the influence of increasing doses of inoculum of Zymoseptoria tritici, on the alveograph and farinograph parameters, BV, bread weight
(BW) and specific volume (SV) among Argentinean wheat cultivars and to establish its possible variation according to the quality group of each cultivar.

\section{Materials and methods}

\subsection{Field trials and experimental design}

Two experiments were carried out at the Experimental Station Julio Hirschhorn in La Plata, Faculty of Agricultural and Forestry Sciences, National University of La Plata during 2010 and 2011. The trials were sown on 15 July and 16 June respectively under conventional tillage. The soil was a Typic Argiudoll. Analysis of the soil samples (top- $0.20 \mathrm{~m}$ ) indicated the following values by weight: organic matter: 3.55\%, N: 0.139\%, P: 15 ppm, pH: 5.75. Weather data (precipitation; relative humidity and minimum, maximum and mean daily temperatures) were recorded at a meteorological station situated $100 \mathrm{~m}$ from the experiments.

The experimental design was a split-split-plot design with three replications. Main plots were the inoculum concentrations: 1- Noninoculated treatment (NI), 2- Low inoculum concentration (LIC) $\left(5 \times 10^{5}\right.$ spores. $\mathrm{ml}^{-1}$ suspension $)$ and 3 - High inoculum concentration (HIC) $\left(5 \times 10^{6}\right.$ spores.ml ${ }^{-1}$ suspension). Sub-plots were the cultivars: Klein Zorro (K. Zorro), Buck 75 Aniversario (B.75 Aniversario), Buck Brasil (B. Brasil), Buck Guapo (B. Guapo) (all of them belonging to quality G1), Klein Escorpión (K. Escorpion), Klein Flecha (K. Flecha), ACA 801 and Relmó Centinela (R. Centinela) (G2), Nidera Baguette 10 (Bag. 10) and Klein Chajá (K. Chaja) (G3). Between the main plots, plots of oats were sown to diminish inter-plot interferences. The entire experiment was fertilized with $50 \mathrm{~kg}$ $\mathrm{P}_{2} \mathrm{O}_{5} \cdot \mathrm{ha}^{-1}$ as calcium triple superphosphate plus $100 \mathrm{~kg} \cdot \mathrm{ha}^{-1} \mathrm{~N}$ as urea at the time of sowing and $80 \mathrm{~kg} \cdot \mathrm{ha}^{-1}$ at the end of tillering.

\subsection{Inoculum preparation}

A mix of virulent isolates (FALP14707, FALP20107, FALP20207 and FALP20507) of Zymoseptoria tritici was used to prepare the inoculum. The isolates were collected from different locations of the Argentinean wheat region, subregion IV (South East of Buenos Aires Province). They were molecularly characterized, belonging to different clusters and showing differences in the reaction on different wheat cultivars (Castillo et al., 2010). The isolates were grown on malt extract agar at $19{ }^{\circ} \mathrm{C}$ with $12 \mathrm{~h}$ alternating light and dark cycles. The inoculum was prepared by aseptically scraping sporulating colonies with a scalpel and suspending conidia in deionized water. The spore concentration was measured with a Neubauer hemocytometer. Conidial suspensions were adjusted to the required concentrations. One milliliter of Tween 20 per liter was added as a surfactant.

Two inoculations were performed (at the beginning of tillering, GS21-GS22, and at flag leaf emergence, GS 39). Plants were sprayed with the inoculum suspension until runoff, using a backpack sprayer for manual application in evening hours. After inoculations, plants were kept moist by spraying with water several times a day with sprinklers during a period of 3 days. Nativo fungicide (trifloxystrobin $120 \mathrm{~cm}^{3} \cdot \mathrm{ha}^{-1}$ and tebuconazole $480 \mathrm{~cm}^{3} . \mathrm{ha}^{-1}$ ) was applied in the NI treatments at GS 22 and GS 39 with a total dose of $600 \mathrm{~cm}^{3} \cdot \mathrm{ha}^{-1}$.

\subsection{Evaluations of disease severity, area under disease progress} curve, green flag leaf area duration and green leaf area duration

Disease severity evaluations were done by visual estimation of the symptoms as a percentage on the two to four uppermost leaves of seven to ten plants, depending on the growth stage of each plot 
at three growth stages (GS 39, 60, 82). The area under disease progress curve (AUDPC) of STB measured in the two upper leaves was calculated according to the formula by Shaner and Finney (1977). The green leaf area index was determined at every growth stage by separating and pasting leaves from seven tillers with at least $10 \%$ green tissues on paper sheets. Then, these sheets were scanned and the leaf area was measured by the image J program (Rasband, 2014). Finally, green leaf area duration (GLAD) and green flag leaf area duration (GFLAD) values were calculated according to the formula developed by Waggoner and Berger (1987).

\subsection{Milling of the samples and determination of quality variables}

The samples of grain from each subplot were cleaned, conditioned to $15.5 \%$ moisture and milled using a Buhler laboratory mill (MLU 202), extracting flour at a rate of about 70\%. Dough rheological properties were evaluated using a Chopin ${ }^{\circledR}$ Alveograph and a Brabender ${ }^{\mathbb{B}}$ Farinograph in accordance with the IRAM standard method 15855:2005 and 15857:2001 respectively. The alveograph values were measured using a $250 \mathrm{~g}$ sample of flour. Tenacity (P) measured in $\mathrm{mm}$, estimates the resistance of the dough and is the maximum height along the ordinate axis. Its length along the $\mathrm{x}$-axis is referred as extensibility $(\mathrm{L})$ measured in $\mathrm{mm}$, the $\mathrm{P} / \mathrm{L}$ ratio and the area under the curve is proportional to the energy required to cause the dough bubble to break named dough strength $(\mathrm{W})$ expressed as $\mathrm{J} \times 10^{-4}$.

The farinograph parameters were measured using a $50 \mathrm{~g}$ sample of flour. Water absorption (A) is the necessary quantity to produce dough with a peak development of 500 Brabender units (B.U) recorded. Development time (B) is the time from the beginning of mixing until the peak resistance (i.e. immediately before the dough shows signs of weakening). Farinographic stability (D) is the time between the top of the resistance curve meeting the maximum consistency measurement (500 B.U) and the point at which it drops below this measurement during dough softening. The degree of softening $(E)$ is the difference between the resistance of the dough at its peak (500 B.U) and 12 min later. Finally, the bread making process was carried out to obtain BV, BW and SV in accordance with the IRAM standard method IRAM 15858-11996. The bread volume (BV) was measured by rapeseed displacement.

\subsection{Statistical analysis}

The AUDPC, GFLAD, GLAD, and quality data were analyzed by ANOVA for a split-split-plot design in a combined analysis for both years with Genstat 12 Ed (VSN, 2011). Inoculation treatments and cultivars were considered as fixed effects whereas replications were considered as random effects. Mean values were compared with Fisher's Protected LSD test $(\mathrm{P}<0.05)$. Considering mean values of GPC and gluten concentration obtained in our previous work (Castro and Simón, 2016), correlation between GPC and gluten concentration were done for mean values in each quality group, treatments NI and treatments HIC.

\section{Results}

\subsection{Meteorological conditions}

Precipitation varied greatly between both years. In 2010, the sum of rainfall during crop cycle was $344 \mathrm{~mm}$ and in 2011 was $481.3 \mathrm{~mm}$. Although mean temperatures were similar for both years, in 2011, the amplitude was lower than in 2010 as minimum temperature was higher and maximum temperature was lower. In November 2011, higher maximum temperature compared to 2010 was observed and during three days the maximum temperature was above $30^{\circ} \mathrm{C}$. Mean humidity was similar for both years ( 71 and 72\% for 2010 and 2011, respectively).

\subsection{Area under disease progress curve, green flag leaf area duration and green leaf area duration}

Analysis of variance of AUDPC caused by STB, for each cultivar and inoculation treatment for both years, is shown in Table 1. In 2011, AUDPC was higher (1953) than in 2010 (1113) for all cultivars and the increase of inoculum concentration caused a marked elevation of AUDPC in 2010 (NI: 758; LIC: 1156; HIC: 1423) and 2011(NI: 1459; LIC: 1951; HIC: 2449). ACA 801, R. Centinela and B. Brasil were the most susceptible cultivars while Bag. 10 was the most resistant cultivar for both growing seasons.

The GFLAD was affected by the main effects, year $\times$ inoculum concentration and year $\times$ cultivar interactions (Table 1 ). GFLAD was higher in 2011 (51 days) compared with 2010 (39 days) and decreased significantly with higher inoculum concentration, being: NI (51 days), LIC (44 days) and HIC (40 days). The year $\times$ cultivar interaction showed that K. Flecha and B.75 Aniversario had the lowest GFLAD in 2010 and 2011 respectively and B. Guapo followed by K. Escorpion and Bag 10 had the highest GFLAD in 2010 whereas ACA 801, K. Flecha and R. Centinela had the highest in 2011 (Fig. 1). The GLAD was modified by all main effects (Table 1). Lower GLAD values were observed in 2010 compared to 2011 and GLAD decreased with the increase in the inoculum concentration. The highest reduction in GLAD was observed in K. Escorpion (65\%) and ACA 801 (53\%) in 2010 while in 2011 the cultivars with the highest losses of GLAD were K. Zorro, ACA 801 and K. Escorpion (36-38\%). The lowest reductions in GLAD were shown by B. 75 Aniversario (21\%), R. Centinela (27\%) and Bag. 10 (29\%) in 2010 and B. Brasil, R. Centinela and Bag. 10 (19-22\%), K. Flecha and B. 75 Aniversario (24\%) in 2011.

\subsection{Correlations between gluten and grain protein concentration}

Considering mean values of gluten concentration and GPC from our previous study on the same experiments (Castro and Simón, 2016), correlation between gluten concentration and GPC was high and significant for cultivars with quality group $1(\mathrm{r}=0.80)$, negative and non-significant for cultivars with quality group 2 and 3. With respect to NI treatment, correlation was very high and significant in cultivars with quality group $1(\mathrm{r}=0.94)$, negative and non-significant for quality group 2 and 3 . Finally, correlations for HIC treatments in each quality group were lower compared with NI treatments and non-significant.

\section{Table 1}

Mean squares (MS) for the combined analysis of variance for area under disease progress curve (AUDPC), green flag leaf area duration (GFLAD), green leaf area duration (GLAD) for ten wheat cultivars under three inoculation treatments with Zymoseptoria tritici in two years.

\begin{tabular}{|c|c|c|c|c|}
\hline \multirow[t]{2}{*}{ Source of variation } & \multirow[t]{2}{*}{ df } & \multirow{2}{*}{$\frac{\text { AUDPC }}{\text { MS }}$} & \multirow{2}{*}{$\frac{\text { GFLAD }}{M S}$} & \multirow{2}{*}{$\frac{\text { GLAD }}{\text { MS }}$} \\
\hline & & & & \\
\hline Year (Y) & 1 & $31,788,758 *$ & $6156^{* *}$ & 308,483 ** \\
\hline Error a & 2 & 121,246 & 18.7 & 446 \\
\hline Inoculum concentration (IC) & 2 & $10,291,204^{* * *}$ & $229^{* * *}$ & $40,172^{* * *}$ \\
\hline Y x IC & 2 & $422,342 *$ & $44.9 *$ & 542 \\
\hline Error b & 8 & 70,855 & 76.9 & 388 \\
\hline Cultivar (C) & 9 & $507,382 * * *$ & $291^{* * *}$ & $2234^{* * *}$ \\
\hline $\mathrm{Y} \times \mathrm{C}$ & 9 & 162,162 & $487^{* * *}$ & 614 \\
\hline IC $\times \mathrm{C}$ & 18 & 71,474 & 69.9 & 599 \\
\hline $\mathrm{Y} \times \mathrm{IC} \times \mathrm{C}$ & 18 & 48,357 & 71.6 & 232 \\
\hline Error c & 108 & 120,760 & 72.4 & 446 \\
\hline
\end{tabular}

${ }^{*} \mathrm{P}<0.05,{ }^{* *} \mathrm{P}<0.01,{ }^{* * *} \mathrm{P}<0.001$ 


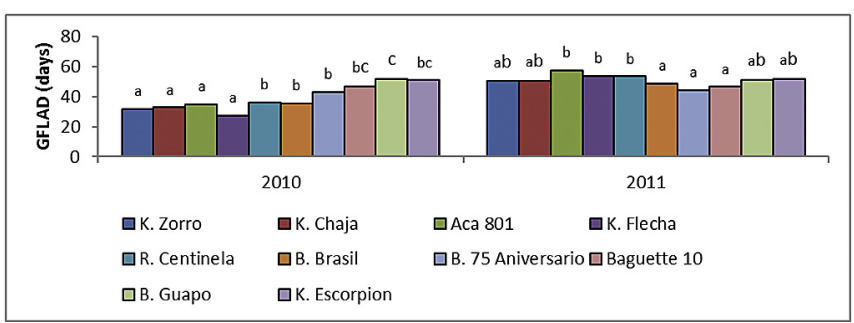

Fig. 1. Green flag leaf area duration (GFLAD) in ten wheat cultivars under three inoculation treatments with Zymoseptoria tritici in two years. Different letters among cultivars in every year indicate significant differences according to LSD test, $\mathrm{P}<0.05$.

\subsection{Alveographic parameters}

Statistical analysis of alveogram parameters is presented in Table 2. Mean values varied according to the quality group of each cultivar. Considering alveogram parameters, the tenacity $(\mathrm{P})$ was affected by inoculum concentration, cultivar, year $\times$ cultivar, inoculum concentration $\times$ cultivar and year $\times$ inoculum concentration $\times$ cultivar interactions (Table 2 ). Tenacity decreased significantly with higher doses of inoculum in most cultivars being 112.4, 103.3 and $98.8 \mathrm{~mm}$ for NI, LIC and HIC respectively. Cultivar K. Flecha showed the highest reduction in P due to the effect of STB in 2010 (30.9\%) and B. 75 Aniversario in 2011 (23.1\%) (Fig. 2).

The extensibility (L) was significantly affected by year, inoculum concentration, cultivar and year $\times$ cultivar interaction (Table 2 ). In 2011 L was higher than in 2010. At higher levels of the disease higher $\mathrm{L}$ values were observed in all cultivars. Mean values were 40.6, 43.1 and $47.1 \mathrm{~mm}$ for NI, LIC and HIC respectively. The year $\times$ cultivar interaction showed that K. Flecha and ACA 801 had the highest values in 2010 and 2011, respectively while ACA 801 and B. Brasil had the lowest P in 2010 and 2011, respectively (Table 3).

The $\mathrm{P} / \mathrm{L}$ ratio was modified by inoculum concentration, cultivar and year $\times$ cultivar (Table 2 ). This relationship decreased when the inoculum concentration augmented. Thus, the NI plots had 2.85, LIC 2.47 and HIC 2.17. B. Guapo, Bag. 10 and B. Brasil had the highest values of $\mathrm{P} / \mathrm{L}$ whereas K. Flecha and K. Chaja had the lowest values. Although year $\times$ cultivar interaction was significant, B. Guapo showed the highest $\mathrm{P} / \mathrm{L}$ in both years (Table 3 ).

The dough strength (W) was affected by year, inoculum concentration, cultivar and year $x$ cultivar (Table 2 ). This parameter was higher in $2011\left(213 \mathrm{~J} \times 10^{-4}\right)$ respect to $2010\left(193 \mathrm{~J} \times 10^{-4}\right)$ and increased with the highest doses of inoculum: NI $\left(192 \mathrm{~J} \times 10^{-4}\right)$, LIC $\left(198 \mathrm{~J} \times 10^{-4}\right)$ and HIC $\left(218 \mathrm{~J} \times 10^{-4}\right)$. B. Guapo, K. Escorpion and K.
Flecha were the cultivars with higher values of $\mathrm{W}$ in 2010 whereas B. 75 Aniversario and B. Guapo in 2011. Cultivars B. 75 Aniversario and K. Chaja, had the lowest W in 2010, also K. Chaja registered the lowest value in 2011 (Table 3).

\subsection{Farinographic parameters}

Statistical analysis for farinographic parameters is presented in Table 2. The water absorption (A) parameter was significantly higher in 2011 (59.7\%) respect to 2010 (57.4\%). Interaction year $\times$ inoculum concentration was significant because A decreased significantly with HIC in 2010, while in 2011 there were not differences among inoculum concentrations. There were also significant differences between cultivars, B. Guapo followed by B. 75 Aniversario, K. Chaja and R. Centinela were the cultivars with the highest values of A. Developmental time (B) presented significant differences only between cultivars (Table 2). Although there were not significant differences between inoculations treatments, the values tended to increase when the inoculum concentration increased. B. Guapo was the cultivar with highest B along with R. Centinela, K. Escorpion and B. Brasil while K. Chaja obtained the lowest $B$. The farinographic stability (D) was modified significantly by inoculum concentration and cultivar (Table 2). Values of $\mathrm{D}$ increased with the inoculum concentration, being 10.4, 12.7 and $13.7 \mathrm{~min}$ for NI, LIC and HIC respectively. In addition, K. Escorpion and B. Brasil were the cultivars with highest D and K. Chaja was the cultivar with lowest D. Degree of softening (E) was affected by year, inoculum concentration, cultivar and the interactions year $\times$ cultivar and year $\times$ inoculum concentration (Table 2 ). In 2010, the E value was lower (61.5 B.U) respect to 2011 (102.9 B.U). There was a decrease in E parameter, as inoculum concentration increased in 2010. The cultivar Bag. 10 had the highest E in 2010 and $\mathrm{K}$. Chaja in 2011 while the lowest value was observed in R. Centinela in 2010 and K. Escorpion in 2011 (Table 3).

\subsection{Bread making aptitude}

Statistical analysis of BW, BV and SV is presented in Table 2. The cultivar ACA 801 had the highest BW while B. Guapo and K. Escorpion had the lowest values. Interaction inoculum concentration $\times$ cultivar was significant as BW decreased between 4.8 and $6.5 \%$ with the increase in inoculum concentration.

There were not differences between years for BV. Inoculation treatment tended to increase BV values significantly (NI: 305, LIC: 306 and HIC: $335 \mathrm{~cm}^{3}$ respectively) and cultivars also showed significant differences, K. Flecha had the highest BV while ACA 801 had the lowest BV. Interaction inoculum concentration $\times$ cultivar

Table 2

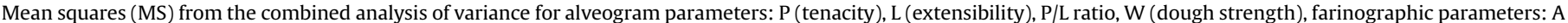

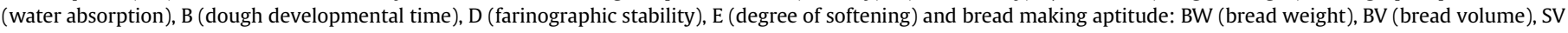
(specific volume) for ten wheat cultivars under three inoculation treatments with Zymoseptoria tritici in two years.

\begin{tabular}{|c|c|c|c|c|c|c|c|c|c|c|c|c|}
\hline \multirow[t]{2}{*}{ Source of variation } & \multirow[t]{2}{*}{$\mathrm{df}$} & \multirow{2}{*}{$\frac{\mathrm{P}(\mathrm{mm})}{\mathrm{MS}}$} & \multirow{2}{*}{$\frac{\mathrm{L}(\mathrm{mm})}{\mathrm{MS}}$} & \multirow{2}{*}{$\frac{\mathrm{P} / \mathrm{L}}{\mathrm{MS}}$} & \multirow{2}{*}{$\frac{\mathrm{W}\left(\mathrm{j} \times 10^{-4}\right)}{\mathrm{MS}}$} & \multirow{2}{*}{$\frac{\mathrm{A}(\mathrm{ml})}{\mathrm{MS}}$} & \multirow{2}{*}{$\frac{\mathrm{B}(\mathrm{min})}{\mathrm{MS}}$} & \multirow{2}{*}{$\frac{\mathrm{D}(\mathrm{min})}{\mathrm{MS}}$} & \multirow{2}{*}{$\frac{\mathrm{E} \text { (U.B) }}{\mathrm{MS}}$} & \multirow{2}{*}{$\frac{\mathrm{BW}(\mathrm{g})}{\mathrm{MS}}$} & \multirow{2}{*}{$\frac{\mathrm{BV}\left(\mathrm{cm}^{3}\right)}{\mathrm{MS}}$} & \multirow{2}{*}{$\frac{\mathrm{SV}\left(\mathrm{cm}^{3} \mathrm{~g}^{-1}\right)}{\mathrm{MS}}$} \\
\hline & & & & & & & & & & & & \\
\hline Year $(Y)$ & 1 & 124 & $832 *$ & 0.81 & $17,208 *$ & $240 *$ & 7.20 & 12.2 & $76,983 * *$ & 13.6 & 307 & 0.003 \\
\hline Error a & 2 & 131 & 31,5 & 0,31 & 519 & 7,38 & 9,40 & 18,1 & 92.0 & 5.32 & 11,640 & 0.597 \\
\hline Inoculum Concentration (IC) & 2 & $2864 * * *$ & $643^{* * *}$ & $7.07^{* * *}$ & $11,044^{* *}$ & 10.9 & 21.1 & $176^{* *}$ & $12,028^{* * *}$ & 103 & $17,776^{* *}$ & $1.18^{* *}$ \\
\hline $\mathrm{Y} \times \mathrm{IC}$ & 2 & 189 & 19.2 & 0.11 & 1282 & $36.2^{* *}$ & 10.7 & 18.0 & $5540 * *$ & 3.74 & 273 & 0.009 \\
\hline Error b & 8 & 100 & 18.2 & 0.12 & 1240 & 3.00 & 6.51 & 18.3 & 607 & 23.1 & 1407 & 0.092 \\
\hline Cultivar (Cu) & 9 & $4140^{* * *}$ & $145^{* * *}$ & $2.82^{* * *}$ & $8996 * * *$ & $36.1^{* * *}$ & $19.6 * * *$ & $172 * * *$ & $9090 * * *$ & $77.9 * *$ & $9226 * * *$ & $0.602^{* * *}$ \\
\hline $\mathrm{Y} \times \mathrm{Cu}$ & 9 & $1697^{* * *}$ & $159^{* * *}$ & $1.96^{* * *}$ & $5086^{* * *}$ & $9.25^{* *}$ & 4.24 & 25.1 & $6523^{* * *}$ & 3.50 & 741 & 0.047 \\
\hline $\mathrm{IC} \times \mathrm{Cu}$ & 18 & $185^{*}$ & 25.1 & 0.19 & 316 & 3.31 & 4.52 & 15.7 & 1187 & $68.7^{* * *}$ & $4643 * * *$ & $0.271^{* * *}$ \\
\hline $\mathrm{Yx}$ IC x Cu & 18 & $188^{*}$ & 36.1 & 0.21 & 657 & 4.04 & 1.80 & 7.78 & 394 & 2.11 & 412 & 0.023 \\
\hline Error c & 108 & 91.4 & 40.5 & 0.15 & 581 & 3.39 & 4.43 & 16.3 & 1036 & 24.7 & 1707 & 0.088 \\
\hline
\end{tabular}

${ }^{*} \mathrm{P}<0.05,{ }^{* *} \mathrm{P}<0.01,{ }^{* * *} \mathrm{P}<0.001$. 


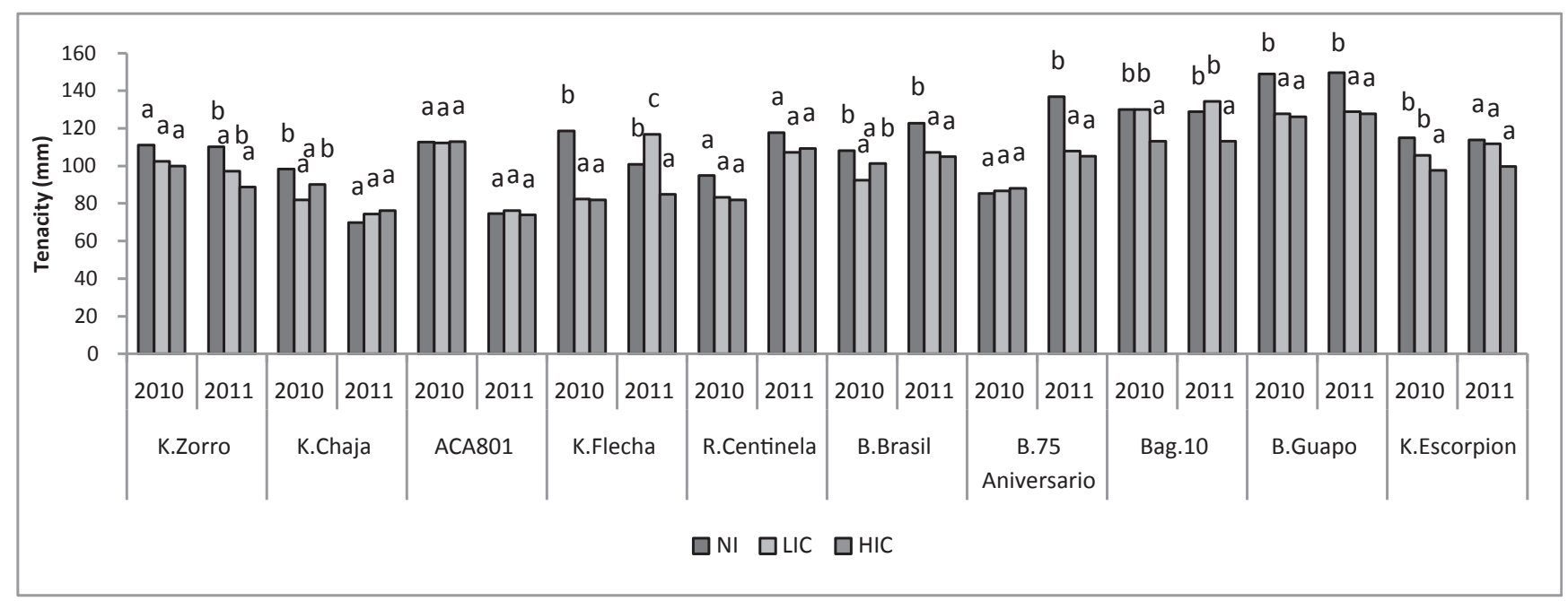

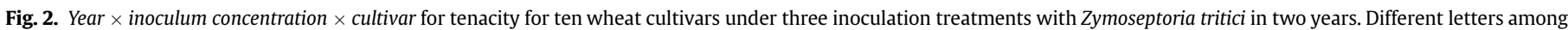
inoculum concentration in every year and every cultivar indicate significant differences according to LSD test $\mathrm{P}<0.05$.

Table 3

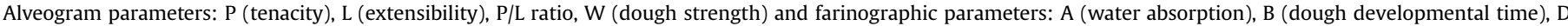

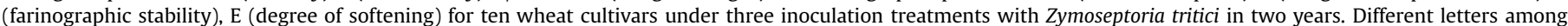
cultivars in every year indicate significant differences according to LSD test $\mathrm{P}<0.05$.

\begin{tabular}{|c|c|c|c|c|c|c|c|c|c|c|c|c|c|c|c|c|}
\hline \multirow[t]{2}{*}{ Cultivars } & \multicolumn{2}{|l|}{$\mathrm{P}(\mathrm{mm})$} & \multicolumn{2}{|l|}{$\mathrm{L}(\mathrm{mm})$} & \multicolumn{2}{|l|}{$\mathrm{P} / \mathrm{L}$} & \multicolumn{2}{|c|}{$\mathrm{W}\left(\mathrm{j} \times 10^{-4}\right)$} & \multicolumn{2}{|l|}{$\mathrm{A}(\mathrm{ml})$} & \multicolumn{2}{|c|}{$\mathrm{B}(\mathrm{min})$} & \multicolumn{2}{|c|}{$\mathrm{D}(\mathrm{min})$} & \multicolumn{2}{|l|}{$\mathrm{E}$ (U.B) } \\
\hline & 2010 & 2011 & 2010 & 2011 & 2010 & 2011 & 2010 & 2011 & 2010 & 2011 & 2010 & 2011 & 2010 & 2011 & 2010 & 2011 \\
\hline K. Zorro & $104 \mathrm{~b}$ & $98.7 \mathrm{~b}$ & $38.7 \mathrm{a}$ & $43.1 \mathrm{ab}$ & $2.72 \mathrm{~b}$ & $2.35 \mathrm{~b}$ & $192 \mathrm{~b}$ & 197 bc & $58.0 \mathrm{~b}$ & $60.2 \mathrm{~b}$ & $6.17 \mathrm{a}$ & $6.78 \mathrm{a}$ & $10.1 \mathrm{a}$ & $10.7 \mathrm{a}$ & 87.8 bc & $75.0 \mathrm{a}$ \\
\hline K. Chaja & $90.2 \mathrm{a}$ & $73.4 \mathrm{a}$ & $38.8 \mathrm{a}$ & $47.8 \mathrm{~b}$ & $2.37 \mathrm{ab}$ & $1.57 \mathrm{a}$ & 159 a & $154 \mathrm{a}$ & $57.7 \mathrm{~b}$ & $61.6 \mathrm{~b}$ & $6.33 \mathrm{a}$ & $5.19 \mathrm{a}$ & $8.34 \mathrm{a}$ & $5.94 \mathrm{a}$ & $67.2 \mathrm{~b}$ & 187 c \\
\hline ACA 801 & $113 \mathrm{c}$ & 74.9 a & $38.2 \mathrm{a}$ & $57.7 \mathrm{c}$ & $2.97 \mathrm{bc}$ & $1.34 \mathrm{a}$ & $201 \mathrm{~b}$ & $184 \mathrm{~b}$ & $54.8 \mathrm{a}$ & $58.3 \mathrm{a}$ & $6.89 \mathrm{a}$ & $6.39 \mathrm{a}$ & $14.1 \mathrm{a}$ & $9.90 \mathrm{a}$ & $44.4 \mathrm{ab}$ & $98.9 \mathrm{ab}$ \\
\hline K. Flecha & $94.4 \mathrm{a}$ & $101 \mathrm{~b}$ & $47.0 \mathrm{~b}$ & $50.3 \mathrm{~b}$ & $2.11 \mathrm{a}$ & $2.14 \mathrm{~b}$ & 214 bc & $209 \mathrm{c}$ & 55.7 a & $60.5 \mathrm{~b}$ & $6.08 \mathrm{a}$ & $6.81 \mathrm{a}$ & $10.1 \mathrm{a}$ & $14.0 \mathrm{a}$ & $44.4 \mathrm{ab}$ & $109 \mathrm{~b}$ \\
\hline R. Centinela & $86.7 \mathrm{a}$ & $111 \mathrm{c}$ & $41.7 \mathrm{ab}$ & $43.7 \mathrm{ab}$ & $2.08 \mathrm{a}$ & $2.57 \mathrm{~b}$ & $171 \mathrm{a}$ & $229 \mathrm{~cd}$ & $58.0 \mathrm{~b}$ & $60.3 \mathrm{~b}$ & $9.61 \mathrm{a}$ & $7.56 \mathrm{a}$ & $14.3 \mathrm{a}$ & $11.1 \mathrm{a}$ & 36.7 a & $94.0 \mathrm{a}$ \\
\hline B. Brasil & $101 \mathrm{ab}$ & $112 \mathrm{c}$ & 38.9 a & $40.6 \mathrm{a}$ & $2.59 \mathrm{~b}$ & $2.80 \mathrm{bc}$ & $172 \mathrm{a}$ & $213 \mathrm{c}$ & $55.4 \mathrm{a}$ & $57.4 \mathrm{a}$ & $8.33 \mathrm{a}$ & $6.69 \mathrm{a}$ & $17.0 \mathrm{a}$ & $17.1 \mathrm{a}$ & $38.9 \mathrm{ab}$ & $77.2 \mathrm{a}$ \\
\hline B. 75 Aniversario & $86.7 \mathrm{a}$ & $117 \mathrm{c}$ & $42.3 \mathrm{ab}$ & $43.4 \mathrm{ab}$ & $2.14 \mathrm{a}$ & $2.74 \mathrm{~b}$ & $156 \mathrm{a}$ & $247 \mathrm{~d}$ & $58.5 \mathrm{~b}$ & $60.9 \mathrm{~b}$ & $7.22 \mathrm{a}$ & $7.61 \mathrm{a}$ & $12.2 \mathrm{a}$ & $10.9 \mathrm{a}$ & $49.2 \mathrm{ab}$ & $101 \mathrm{ab}$ \\
\hline Baguette 10 & $124 \mathrm{~d}$ & $126 \mathrm{~d}$ & $43.7 \mathrm{ab}$ & $44.2 \mathrm{ab}$ & $2.92 \mathrm{bc}$ & $2.97 \mathrm{c}$ & 213 bc & $225 \mathrm{c}$ & $57.3 \mathrm{~b}$ & $58.4 \mathrm{a}$ & $6.94 \mathrm{a}$ & $7.06 \mathrm{a}$ & $11.3 \mathrm{a}$ & $11.2 \mathrm{a}$ & $104 \mathrm{c}$ & $97.2 \mathrm{a}$ \\
\hline B. Guapo & $134 \mathrm{e}$ & $135 \mathrm{e}$ & $42.0 \mathrm{ab}$ & $41.3 \mathrm{ab}$ & $3.23 \mathrm{c}$ & $3.31 \mathrm{c}$ & $236 \mathrm{c}$ & $247 d$ & $60.6 \mathrm{c}$ & $60.9 \mathrm{~b}$ & $9.28 \mathrm{a}$ & $8.56 \mathrm{a}$ & $10.7 \mathrm{a}$ & $10.7 \mathrm{a}$ & $95.0 \mathrm{bc}$ & $119 \mathrm{~b}$ \\
\hline K. Escorpion & $106 \mathrm{bc}$ & 108 bc & $43.1 \mathrm{ab}$ & $45.2 \mathrm{ab}$ & $2.49 \mathrm{~b}$ & $2.49 \mathrm{~b}$ & $216 \mathrm{c}$ & $224 \mathrm{c}$ & $57.6 \mathrm{~b}$ & $58.4 \mathrm{a}$ & $8.28 \mathrm{a}$ & $8.50 \mathrm{a}$ & $17.1 \mathrm{a}$ & $18.4 \mathrm{a}$ & $47.2 \mathrm{ab}$ & $71.7 \mathrm{a}$ \\
\hline
\end{tabular}

was significant as ACA 801, K. Flecha, B. Brasil and K. Escorpion increased BV with HIC, whereas the rest of cultivars did not present significant modifications in BV values (Fig. 3).

The SV showed significant differences among inoculation treatments, cultivars and interaction inoculum concentration $\times$ cultivar (Table 2 ). There was a tendency to augment SV with the increase in inoculum concentration that was significant in ACA 801, K. Flecha, B. Brasil and K. Escorpion.

\section{Discussion}

Meteorological conditions (higher temperature, higher precipitation and relative moisture) after the inoculation with Zymoseptoria tritici were more conducive for the development of the disease in 2011 than in 2010, causing an increase in the disease severity at all GS and therefore in the AUDPC. Hess and Shaner (1987) found that disease severity increased when post-infection

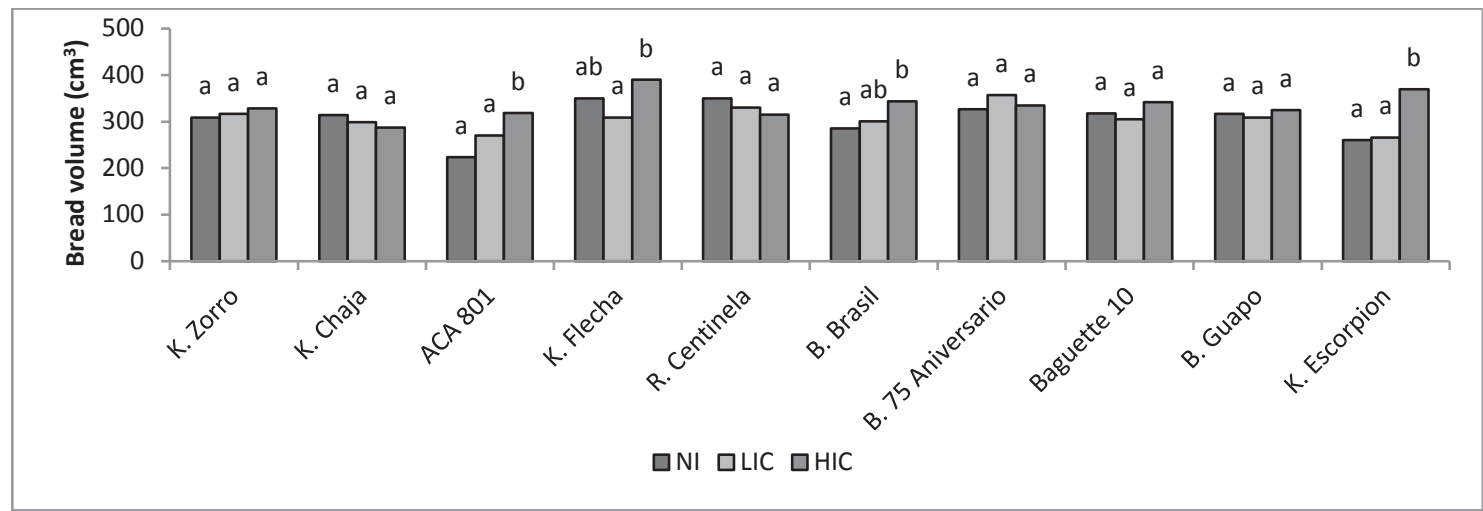

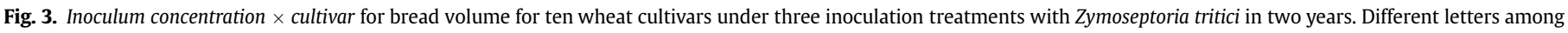
inoculum concentration in every cultivar indicate significant differences according to LSD test $\mathrm{P}<0.05$. 
temperature or post-inoculation moist periods were higher, and the greatest severities resulted from combinations of long moist periods $\left(96 \mathrm{~h}\right.$ ) and temperatures between 20 and $25^{\circ} \mathrm{C}$. Predisposing weather conditions in 2011 also caused higher values of GFLAD and GLAD in 2011 with respect to 2010. STB has been associated with yield losses, due to the reduction of the photosynthetic life of the canopy, especially in the flag leaf, during grain filling (Puppala et al., 1998). In our previous work for the same experiments (Castro and Simón, 2016), the inoculation with Zymoseptoria tritici reduced GY, yield components and test weight, according to other researchers (Simón et al., 2002).

Grain protein concentration is the factor that more widely influences the quality of the flour derived from that grain (FuertesMendizábal et al., 2010). However, the amount of gluten and protein is not always directly associated with quality, since high protein and/or gluten contents may not be indicating good behavior in the W (Cuniberti et al., 2004). In our previous work about these experiments (Castro and Simón, 2016), GPC, wet and dry gluten evidenced an increment with the inoculum concentration. The lower GY caused an increase in GPC due to a concentration effect, in agreement with Dimmock and Gooding (2002a). Contrasting results have been found about the effect of STB on GPC. Arabi et al. (2007) found a GPC reduction due to STB which varied according to the susceptibility of the cultivar used while Watson et al. (2010) found an increase in GPC of $0.004 \%$ for every $1 \%$ increase in STB severity.

The correlations between GPC and gluten concentration made with the data presented in our previous work (Castro and Simón, 2016), evidenced that the relationship between gluten concentration and GPC was positive and significant in quality group 1 $(\mathrm{r}=0.80)$ and non-significant in cultivars belonging to quality group 2 and 3. In the same way, Cuniberti et al. (2004) suggested that it was possible to expect the same variability in the expression of the amount of gluten regardless of the quality group, with a slight tendency to decrease in the cultivars of quality group 3.

As indicated above, STB also affected rheological and breadmaking properties, higher doses of inoculum concentration decreased alveographic parameters $\mathrm{P}, \mathrm{P} / \mathrm{L}$ ratio while increased $\mathrm{L}$ and W. In a similar way, Fleitas et al. (2016) found that tan spot produced a decrease in $\mathrm{P}(9.54 \%)$ but increased $\mathrm{W}$ (14.7\%) significantly compared to leaf rust. This could be explained in part because the increment in GPC due to a lower GY caused an increase in some rheology properties such as L and W. Grain protein composition is compounded by storage proteins: gliadins that tend to impart plasticity and elasticity (extensibility) to dough, and glutenin, that impart strength (tenacity). An optimum balance between them is desirable to achieve dough that does not require excessive mixing energy to reach peak development (Stone and Savin, 1999). The gliadins are the first storage proteins accumulated in the grain and make their first appearance five to ten days after anthesis, while glutenins are frequently the last proteins to appear in the grain, until as late as twenty days after anthesis. The occurrence of stresses during this period could modify gliadin/ glutenin ratio (Stone and Savin, 1999).

Some authors showed that STB reduced grain filling period (Dimmock and Gooding, 2002b; Pepler et al., 2006), so there will be proportionally more gliadins, because glutenins are the most affected and the relation gliadins/glutenins increases, influencing on the rheological properties (Stone and Savin, 1999). In our study, the cultivars K. Flecha and B. 75 Aniversario with the lowest GFLAD in 2010 and 2011 respectively, presented the highest decrease of $P$ values and the highest $\mathrm{L}, \mathrm{W}$ and $\mathrm{BV}$ values which can be related with a high gliadin/glutenin relationship.

In addition the higher L values found in 2011 compared to 2010 can be explained by the hypothesis that occasional episodes of high temperatures during grain filling activates elements associated with genes encoding gliadins, increasing their content in mature seeds. In November 2011 maximum temperature was above $30^{\circ} \mathrm{C}$ during three days. As a consequence, the mature grain has a higher gliadin/glutenin ratio compared to 2010 and produces weaker doughs with shorter development times (Blumenthal et al., 1993).

Farinographic parameters A, related with the amount of bread obtained per kilo of flour and B values related with the quality of gluten and water absorption did not show changes due to STB while $\mathrm{D}$, indicating the time that maximum dough consistence is maintained, increased and E, decreased with higher doses of inoculum concentration. Cultivars differed among them for all farinographic parameters. Differences in farinograph parameters among cultivars were according to the quality group of each cultivar. Similarly, Denčić et al. (2011) found that ranges of some quality parameters were significantly higher across cultivars than across environments. Furthermore, the BV was increased with higher doses of inoculum concentration possibly due to the increment in $\mathrm{L}$ and $\mathrm{W}$.

\section{Conclusions}

STB affected rheological properties of bread wheat causing a decrease in $\mathrm{P}, \mathrm{P} / \mathrm{L}$ and $\mathrm{E}$ and an increase in $\mathrm{L}, \mathrm{W}, \mathrm{D}, \mathrm{BV}$ and $\mathrm{SV}$. Those results indicated that the control of the disease with fungicides not only will cause an increase in yield, but also an improvement in the relation $\mathrm{P} / \mathrm{L}$ due to an increase in GFLAD and enlargement of the grain filling duration. Cultivars differed among them for all alveogram, farinographic and bread making aptitude parameters according to quality group. The relationship between gluten concentration and GPC was positive and significant in quality G1 and non-significant in cultivars belonging to quality G2 and G3. The correlations for HIC treatments in each quality group were lower compared with NI treatments and non-significant.

\section{Acknowledgements}

We wish to thank the staff from the J. Hirschhorn Experimental Station, Faculty of Agricultural and Forestry Sciences, National University of La Plata, Argentina for technical assistance during the field experiments.

\section{Funding}

This study was supported by, National Council for Scientific and Technological Research (CONICET) PIP 11220130100819CO, National University of La Plata (UNLP) A 300 and National Agency for Scientific and Technological Promotion (ANPCyT) PICT 2181/2010.

\section{References}

Arabi, M.I., Jawar, M., Mir Ali, N., 2007. The effect of Mycosphaerella graminicola infection on wheat protein content and quality. Cereal Res. Commun. 35, 81-88. http://dx.doi.org/10.1556/CRC.35.2007.1.10.

Blumenthal, C., Barlow, E.W.R., Wrigley, C.W., 1993. Growth environment and wheat quality: the effect of heat stress on dough properties and gluten proteins. J. Cereal Sci. 18, 3-21. http://dx.doi.org/10.1006/jcrs.1993.1030.

Castillo, N., Cordo, A.C., Simón, M.R., 2010. Molecular variability among isolates of Mycosphaerella graminicola, the causal agent of Septoria Tritici Blotch. Phytoparasitica 38, 379-389.

Castro, A.C., Simón, M.R., 2016. The effect of tolerance to Septoria tritici blotch in grain yield, yield components and quality among Argentinean wheat cultivars. Crop Prot. 90, 66-76. http://dx.doi.org/10.1016/j.cropro.2016.08.015.

Cuniberti, M., Bainotti, C., Fraschina, J., Salines, J., Alberione, E., Riberi, L., Galich, A. Galich, M.T., de Galich Formica, M.B., 2004. Calidad de cultivares de trigo evaluados en ensayos de control químico de enfermedades foliares. Trigo Actualización 2004. In: Información para extensión № 85. INTA, Marcos Juárez, Córdoba, pp. 38-43.

Denčić, S., Mladenov, N., Kobiljski, B., 2011. Effects of genotype and environment on breadmaking quality in wheat. Int. J. Plant Prod. 5, 71-82. http://dx.doi.org/ 
10.22069/ijpp.2012.721

Dimmock, J.P.R.E., Gooding, M.J., 2002a. The influence of foliar diseases, and their control by fungicides, on the protein concentration in wheat grain: a review. J. Agric. Sci. 138, 349-366. http://dx.doi.org/10.1017/S0021859602002058.

Dimmock, J.P.R.E., Gooding, M.J., 2002b. The effects of fungicides on rate and duration of grain filling in winter wheat in relation to maintenance of flag leaf green area. J. Agric. Sci. 138, 1-16. http://dx.doi.org/10.1017 S0021859601001666.

Dupont, F.M., Altenbach, S.B., 2003. Molecular and biochemical impacts of environmental factors on wheat grain development and protein synthesis. J. Cerea Sci. 38, 133-146. http://dx.doi.org/10.1016/S0733-5210(03)00030-4.

Finlay, G.J., Bullock, P.R., Sapirstein, H.D., Naeem, H.A., Hussain, A., Angadi, S.V. DePauw, R.M., 2007. Genotypic and environmental variation in grain, flour dough and bread-making characteristics of western Canadian spring wheat. Can. J. Plant Sci. 87, 679-690. http://dx.doi.org/10.4141/P06-150.

Fleitas, M.C. Schierenbeck, M., Golik, S.I., and Simón, M.R. 2016. La calidad panader y dinámica del área foliar verde de trigo pan, frente a mancha amarilla y roya de la hoja. Revista técnica cultivos invernales/Edición 2016. Revista Técnica de la Asociación Argentina de Productores en Siembra Directa (AAPRESID) ISSN 1850-0633, Pág. 48-54.

Fones, H., Gurr, S., 2015. The impact of Septoria tritici blotch disease on wheat: an EU perspective. Fungal Genet. Biol. 79, 3-7. http://dx.doi.org/10.1016/j.fgb.2015 04.004.

Fuertes-Mendizábal, T., Aizpurua, A., González-Moro, M.B., Estavillo, J.M., 2010. Improving wheat breadmaking quality by splitting the $\mathrm{N}$ fertilizer rate. Eur. J. Agron. 32, 52-61. http://dx.doi.org/10.1016/j.eja.2010.03.001.

González Montaner, J.G., and Di Nápoli, M. 2005. Genotypic variability of commercial varieties of wheat bread in parameters of commercial and industrial quality. 7th International wheat Conference. 27 de Noviembre al 2 de Diciembre, Mar del Plata, Argentina. pp.72.

Hess, D.E., Shaner, G., 1987. Effect of moisture and temperature on development of Septoria tritici blotch in wheat. Am. Phytopathol. Soc. Phytopathology 77, 215-219. http://dx.doi.org/10.1094/Phyto-77-215.

IRAM standard method Chopin alveograph: 15855:2005, Brabender farinograph: 15857:2001, Experimental breadmaking: IRAM 15858-1 1996.

Ishikawa, S., Hare, M.C., Kettlewell, P.S., 2001. Nitrogen accumulation in grains of wheat in response to strobilurins fungicides. Aspects Appl. Biol. Wheat Qual. 64 235-236.

McKendry, A.L., Henke, G.E., Finney, P.L., 1995. Effects of Septoria Leaf Blotch on soft red winter wheat milling and baking quality. Cereal Chem. 72, 142-146.

Pepler, S., Gooding, M.J., Ellis, R.H., 2006. Modelling simultaneously water content and dry matter dynamics of wheat grains. Field Crops Res. 95, 49-63. http:// dx.doi.org/10.1016/j.fcr.2005.02.001.

Puppala, V., Herrman, T.J., Bockus, W.W., Loughin, T.M., 1998. Quality responses of twelve hard red winter wheat cultivars to foliar disease across four locations in central Kansas. Cereal Chem. 75, 148-151. http://dx.doi.org/10.1094/ CCHEM.1998.75.1.94.

Rasband, W.S., 2014. ImageJ. U. S. National Institutes of Health, Bethesda, Maryland, USA, p. 1997. http://imagej.nih.gov/ij.

Rees, R.G., Platz, G.J., Mayer, R.J., 1982. Yield losses in wheat from yellow spot: comparison of estimates derived from single tillers and plots. Aust. J. Agric. Res. 33, 899-908. http://dx.doi.org/10.1071/AR9820899.

Ruske, R.E., Gooding, M.J., Pepler, S., Froggatt, P., 2001. Nitrogen accumulation in grains of winter wheat in response to strobilurin fungicides. Aspects Appl. Biol. Wheat Qual. 64, 227-234.

Shaner, G., Finney, R.E., 1977. The effect of nitrogen fertilization on the expression of slow-mildewing resistance in Knox wheat. Phytopathology 67, 1051-1056. http://dx.doi.org/10.1094/Phyto-67-1051.

Simón, M.R., Perelló, A.E., Cordo, C.A., Struik, P.C., 2002. Influence of Septoria tritici on yield, yield components, and test weight of wheat under two nitrogen fertilization conditions. Crop Sci. 42, 1974-1981. http://dx.doi.org/10.2135/ cropsci2002.1974.

Stone, P.J., Savin, R., 1999. Grain quality and its physiological determinants. In: Satorre, E.H., Slafer, G.A. (Eds.), Wheat: Ecology and Physiology of Yield Determination. Food Product Press, New York, pp. 50-120.

USDA, 2016. World Agricultural Production. USDA Foreign Agricultural Service, Washington D C, p. 20250

VSN International, 2011. GenStat for Windows, fourteenth ed. VSN International, Hemel Hempstead, UK GenStat.co.uk.

Waggoner, P.E., Berger, R.D., 1987. Defoliation, disease and growth. Phytopathology 77, 393-398.

Watson, A.M., Hare, M.C., Kettlewell, P.S., Brosnan, J.M., Agu, R.C., 2010. Relationships between disease control, green leaf duration, grain quality and the production of alcohol from winter wheat. J. Sci. Food Agric. 90, 2602-2607. http:// dx.doi.org/10.1002/jsfa.4128.

Zadoks, J.C., Chang, T.T., Konzak, C.F., 1974. A decimal code for the growth stages of cereals. Weed Res. 14, 415-421. http://dx.doi.org/10.1111/j.13653180.1974.tb01084.x. 